\title{
EDTA-extractable Proteins from Calf Lens Fiber Membranes are Phosphorylated by $\mathrm{Ca}^{2+}$-phospholipid-dependent Protein Kinase
}

\author{
A.J.M. Van din Elinden-van RaAiJ, A. FeiJen and G. T. SNokk \\ Hubrecht Laboratory, Netherlands Institute for Developmental Biology, \\ Utrecht, The Netherlands
}

(Received 17 January 1987 and accepted in revised form 8 March 1987)

\begin{abstract}
A distinct group of EDTA-extractable proteins (EEP), being a major protein component of calf lens fiber membranes, is bound to these membranes in a caleium-dependent way. Both purified and membrane-bound EEP can be phosphorylated in vitwo by a $\mathrm{Ca}^{24}$-artivated, phospholipiddependent protein kinase (protein kinase (). In general, this protein kinase preferentially phosphorylates serine and threonine residues of protein substrates. Phosphoumino-acid analysis of the two major bands of ECP phosphorylated by protein kinase $C$, representing the $33(000+34000$ FEP proteins and the $30700-31800$ proteins, respectively, revealed differences in the phosphoaminoacid patterns. For the $33000+34000$ EEP proteins, only phosphothreonine was detected whereas for the $30700-31800$ proteins, the label was incorporated in both threonine and serine residues. No label was found on tyrosine residues. These results implicate differences in the primary strueture of the individual EEP proteins. Regarding previous observations that EEP is a main protein component of lens fiber junctions and of the many covering epithelial and endothelial cells, and considering the fact that protein kinase $C$ is involved in cell-cell communication, growth and differentiation processes we suggest that a correlation exists between phosphorylation-dephosphorylation of EEP and the regulation of a number of cellular processes.

Key words: lens; membranes; membrane protein; EDTA-extractable protein; Ca ${ }^{2+}$-phospholipid-dependent protein kinase.
\end{abstract}

\section{Introduction}

The vertebrate eye lens is an organ in which both growth and differentiation processes occur. Proliferating epithelial cells are localized as a subcapsular monolayer at the anterior surface of the lens. In the equatorial zone these cells elongate and differentiate into fiber cells. Differentiation of epithelial cells is accompanied witis a large increase in cell surface. New plasma membranes are formed while other membranous cell organelles are lost. The fiber cells are deposited in layers around the central part (nucleus) of the lens, which still contains differentiated epithelial cells nriginating from the embryological stage.

In the past few years both mitogenic factors and factors that promote differentiation of lens epithelial cells have been discovered in the eye. In chicken vitreous humour an activity, called lentropin, has been identified which induces differentiation of embryonic chicken lens epithelial cells (Beebe, Feagans and Jebens, 1980). On the other hand, many ocular tissues including retina, iris, choroid and vitreous body have been shown to contain activities which can stimulate growth of bovine epithelial cells in vitro (Barritault, Arruti and Courtois, 1981). Analysis of these eye-derived growth factor (EDGF) activities revealed the presence of a growth factor being analogous to the acidic form of fibroblast growth factor (EDGF-II; Schreiber et al., 1985a) as well as a basic fibroblast growth factor-like activity

Please send correspondence to Dr A.J.M. van den Eijnden-van Raaij, Hubrecht Laboratory. Netherlands Institute for Developmental Biology. Uppsalalann 8, 3584 CT Utrecht. The Netherlands.

$0014-4835 / 87 / 080215+11 \$ 03.00 / 0$

(C) 1987 Academic Press Inc. (London) Limited 
(EDGF-I; Courty et al., 1985). Furthermore, evidence has been obtained for the occurrence of a specific membrane receptor for EDGF-1 on bovine epithelial lens cells (Moenner, Chevallier, Badet and Barritault, 1986). However, the mechanisms underlying growth stimulation and differentiation of lens epithelial cells are poorly understood.

Recently the presence of a $\mathrm{Ca}^{2+}$, and phospholipid-dependent protein kinase (protein kinase $C$ ) in the lens has been described (Lampe, Bazzi, Nelsestuen and Johnson, 1986). Protein kinase $C$ is thought to play an important role in signal transduction for a number of cellular processes (Nishizuka, 1984a,b). Activation of this enzyme occurs by diacylglycerol which is generated after breakdown of phosphatidylinositol (Nishizuka, 1984a). This phosphatidylinositol turnover in turn is the indirect result of interactions between growth factors or hormones and their receptors (Habenicht et al., 1981 ; Berridge, Heslop, Irvine and Brown, 1984). Protein kinase $\mathrm{C}$ is activated by $\mathrm{Ca}^{2+}$-dependent association with acidic phospholipids in the plasma membrane. Upon activation of protein kinase $\mathrm{C}$ specific intracellular proteins are phosphorylated on serine and threonine residues (Takai, Kishimoto and Nishizuka; 1982). In this study we examined the capacity of protein kinase $C$ to phosphorylate a group of extrinsic EDTA-extractable proteins (EEP) which are bound via calcium to acidic phospholipids in the lens fiber membrane (van Raaij, de Leeuw and Broekhuyse, 1983a; van den Eijnden-van Raaij, de Leeuw and Broekhuyse, 1985a). The results are compared with those of in vivo phosphorylation experiments of lens tissue (Johnson, Lampe, Chung Hur, Louis and Johnson, 1986) and the possible implications of EEP phosphorylation by protein kinase $\mathrm{C}$ for several cellular events are discussed.

\section{Materials and Methods}

\section{Preparation of lens fiber membranes and purification of EEP}

Fiber membranes were prepared from whole decapsulated 4-month-old calf lenses in the presence or absence of $1 \mathrm{~mm} \mathrm{CaCl}{ }_{2}$ or in $50 \mathrm{~mm}$ Tris-5 mM EGTA ( $\mathrm{pH} \mathrm{8.0)}$ as described by van Raaij, de Leeuw and Broekhuyse (1983b).

Lens fiber EEP was isolated and purified according to the method of van Raaij et al., (1983a). The EEP solution was dialysed against $1 \mathrm{~mm}$ Tris- $\mathrm{HCl}(\mathrm{pH} 8.0)$ overnight at $4^{\circ} \mathrm{C}$ to remove EDTA, lyophilized and dissolved in water to a final concentration of $10 \mathrm{mg} \mathrm{ml}^{-1}$.

\section{Purification of protein kinase $C$}

Protein kinase $\mathrm{C}$ was purified from mouse brain essentially as described earlier (Inoue, Kishimoto, Takai and Nishizuka, 1977 ; Snoek, Rosenberg, de Laat and Gitler, 1986). Murine brains were homogenized in $20 \mathrm{~mm}$ Tris $(\mathrm{pH} 7.5): 250 \mathrm{~mm}$ sucrose:2 mM EDTA:10 mM EGTA and centrifuged for $90 \mathrm{~min}$ at $21500 \mathrm{rpm}$ in a Beckman SW 27 rotor. The supernatant was applied to a DE-52 anion-exchange column, equilibrated with $20 \mathrm{~mm}$ Tris $(\mathrm{pH} 7 \cdot 5): 2 \mathrm{~mm}$ EDTA : $5 \mathrm{~mm}$ EGTA : $50 \mathrm{~mm} \beta$-mercaptoethanol. The enzyme was eluted by application of a linear $\mathrm{NaCl}$ concentration gradient $(0-0.4 \mathrm{M})$ in the same buffer. The fractions containing protein kinase $\mathrm{C}$ activity were pooled, concentrated and applied to a Sephadex G-100 column equilibrated in $20 \mathrm{~mm}$ Tris (pH 7.5):0.5 m EGTA :50 m $\beta$-mercaptoethanol. Elution was carried out with the same buffer and the protein-kinase-C-containing fractions were pooled, concentrated and $\mathrm{NaCl}$ was added to a final concentration of $3 \mathrm{M}$. The preparation was applied to a phenyl Sepharose Cl 4B column equilibrated in $20 \mathrm{~mm}$ Tris (pH 7.5):2 mM EDTA, $50 \mathrm{~mm} \beta$-mercaptoethanol:3 $\mathrm{M} \mathrm{NaCl}$. The column was washed with the same buffer containing $0.5 \mathrm{M} \mathrm{NaCl}$ and the enzyme was eluted with the buffer without $\mathrm{NaCl}$. Triton $\mathrm{X}-100(0.01 \%)$ and glycerol $(20 \%)$ were added to stabilize the enzyme. The enzyme was kept at $4^{\circ} \mathrm{C}$ and was found to be stable for several weeks. 
Protein kinase C assay

The $\mathrm{Ca}^{2+}$ - and phospholipid-dependent protein kinase activity was assayed by adding $0 \cdot 1-1 \mu \mathrm{g}$ of purified protein kinase C to a reaction mixture (final volume $125 \mu \mathrm{l}$ ) of $20 \mathrm{~mm}$ Tris (pH 7.5):7.5 mM MgAc: $10 \mu \mathrm{g} \mathrm{m}]^{-1}$ leupeptin : $200 \mu \mathrm{g} \mathrm{ml}^{-1}$ histone IIIs: $10 \mu \mathrm{M} \mathrm{ATP:06} \mu \mathrm{g} \mathrm{ml}^{-1}$ phosphatidylserine (PS; isolated from bovine spinal cord) $: 3 \cdot 2 \mu \mathrm{g} \mathrm{m}^{-1}$ diolein $: 1 \mathrm{~mm} \mathrm{CaCl}_{2}$. The control value was determined in the same reaction mixture without PS, diolein and (or) $\mathrm{CaCl}_{2}$, with $1 \mathrm{~mm}$ EGTA added. The mixtures were pre-incubated for $5 \mathrm{~min}$ at $30^{\circ} \mathrm{C}$. The reaction was started by the addition of ATP and $\left(\gamma^{32}\right.$ P)ATP $\left(10 \mu \mathrm{M}, 2 \times 10^{6} \mathrm{cpm}\right.$ per incubation) and allowed to proceed at $30^{\circ} \mathrm{C}$ for $4 \mathrm{~min}$. The reaction was stopped by pipetting $100 \mu \mathrm{l}$ of the reaction mixture into $1 \mathrm{ml}$ ice-cold $25 \%$ trichloroacetic acid. The precipitated protein was collected on a Millipore filter $(0.45 \mu \mathrm{m})$, washed five times with $3 \mathrm{ml}$ ice-cold $10 \%$ trichloroacetic acid: $10 \mathrm{~mm}$ sodium pyrophosphate and radioactivity was measured.

In vitro phosphorylation of lens fiber membranes and EEP

The composition of incubation mixtures was as described for the protein kinase $\mathrm{C}$ assay. Instead of histones, lens fiber membranes (100 $\mu \mathrm{g}$ per assay) or purified lens fiber EEP (25 $\mu \mathrm{g}$ per assay) were added. One microgram of purified protein kinase $\mathrm{C}$ was added and the mixtures were pre-incubated at $30^{\circ} \mathrm{C}$ for $5 \mathrm{~min}$. Phosphorylation was started by the addition of ATP $(3 \mu \mathrm{M})$ and $\left(\gamma_{-}{ }^{32} \mathrm{P}\right) \mathrm{ATP}\left(2 \mu \mathrm{Ci}\right.$ per assay) and allowed to proceed for $5 \mathrm{~min}$ at $30^{\circ} \mathrm{C}$. Twenty-five microliters of the incubation mixture was treated as described for the protein kinase $\mathrm{C}$ assay to calculate the $\mathrm{Ca}^{2+}$-phospholipid-dependent phosphorylation. To the remaining $100 \mu \mathrm{l}, 50 \mu \mathrm{l}$ of sample buffer (Laemmli, 1970) was added and SDS-polyacrylamide gel electrophoresis was performed in $10 \%$ gels according to Laemmli (1970). Autoradiography of the gels was performed using XAR-5 film (Kodak).

\section{Phosphoaminoacid analysis by high-voltage electrophoresis}

The stained protein bands required were excised from the dried SDS-polyacrylamide gel, allowed to swell in $\mathrm{NH}_{4} \mathrm{HCO}_{3}(100 \mathrm{~mm})$, and incubated in trypsin $\left(100 \mu \mathrm{g} \mathrm{ml}^{-1}\right)$ for $24 \mathrm{hr}$ at $37^{\circ} \mathrm{C}$ on a shaker to elute labeled proteins. The elutant was centrifuged and the supernatant dialyzed at $4^{\circ} \mathrm{C}$ against $\mathrm{H}_{2} \mathrm{O}$ then dried under reduced pressure. The dry sample was hydrolyzed in $0.4 \mathrm{ml} \mathrm{HCl}(6 \mathrm{~m})$ for $2 \mathrm{hr}$ at $110^{\circ} \mathrm{C}$ under vacuum. $\mathrm{HCl}$ was then removed under reduced pressure, the hydrolysates were resuspended in $10 \mu \mathrm{l} \mathrm{H}_{2} \mathrm{O}$ containing $10 \mu \mathrm{g}$ each of marker phosphoserine, phosphothreonine, and phosphotyrosine and analysed by onedimensional, high-voltage paper electrophoresis at pH $3.5(1500 \mathrm{~V}, 1.5 \mathrm{hr})$ in $5 \%$ glacial acetic acid, $5 \mathrm{~mm}$ EDTA. The markers were visualized by ninhydrin staining and radioactive material localized autoradiographically.

\section{Analytical procedures}

Protein determinations of lens fiber membrane suspensions were carried out according to Lees and Paxman (1972) using bovine serum albumin as a standard. For EEP solutions the Bio-Rad protein micro assay (Bradford, 1976) was used.

Preparation of an antiserum which is specific for EEP (anti-EEP antiserum) and the immunological detection of EEP on nitrocellulose sheets have been described (van Raaij, de Leeuw, Janssen and Broekhuyse, 1983c).

\section{Results}

\section{Characterization of lens of fiber membrane proteins}

The plasma membranes of lens fiber cells are mainly composed of lipids, integral and peripheral proteins (Broekhuyse; 1983). The membrane proteins can be separated from the other protein constituents of lens fiber cells because of their differential solubilization properties. Treatment of the fiber cells with buffer removes the watersoluble crystallins and subsequent extraction with $8 \mathrm{M}$ urea solubilizes the cytoskeleton resulting in a crystallin-free, cytoskeleton-free membrane preparation (Broekhuyse, 1981; Harding and Dilley, 1976; Bloemendal, 1981, 1982). 

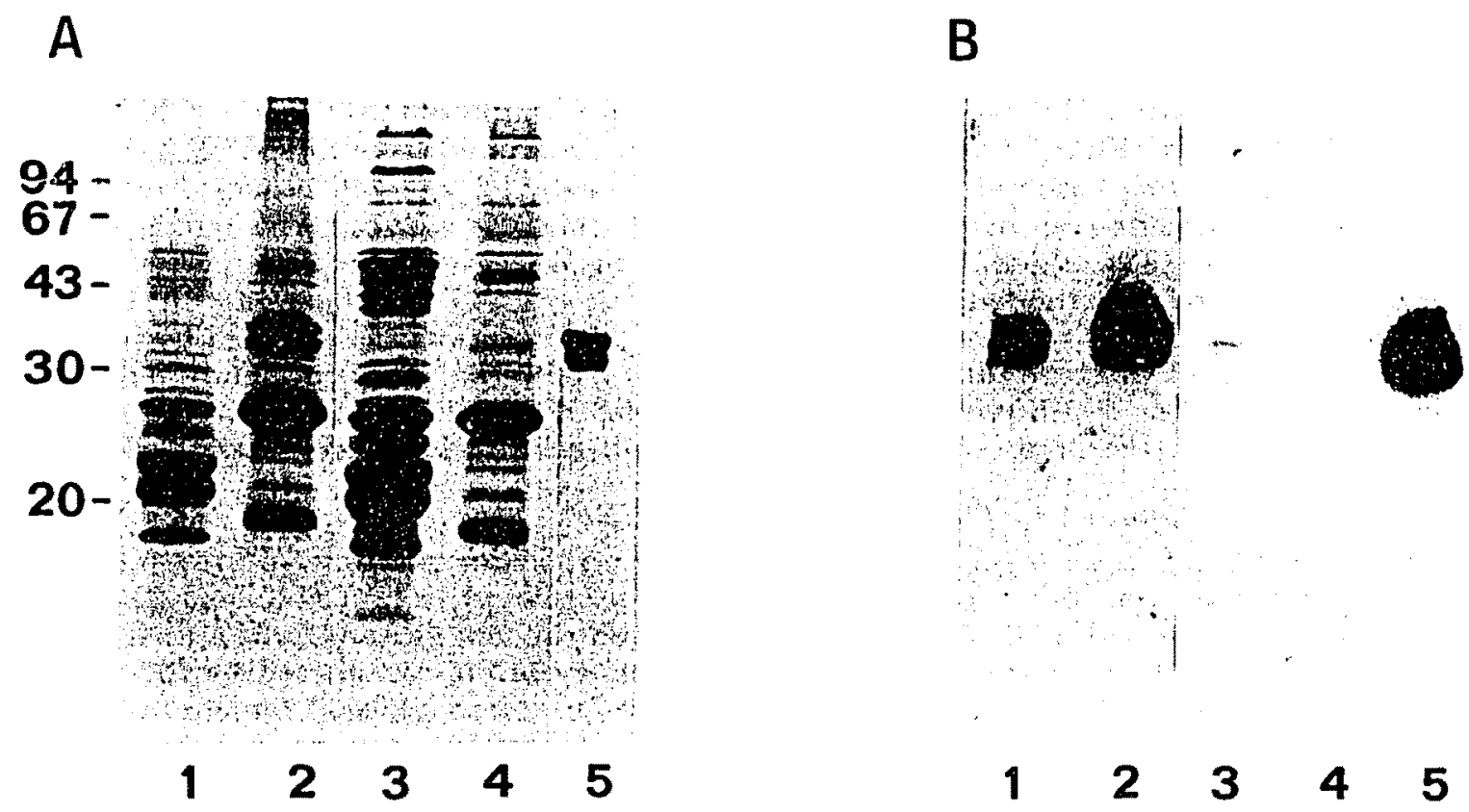

Fia. 1. (a), SDS-gel electrophoresis $(13 \%$ gel, $0.75 \mathrm{~mm})$ of buffer-washed calf lens fiber membranes (odd-numbered lanes) and urea-treated membranes (even-numbered lanes) isolated in $\mathrm{Tris}_{-\mathrm{CaCl}}$ (lanes 1 and 2 ) and Tris-EDTA buffer (lanes 3 and 4). Lanes $1-4$ all contain $30 \mu g$ protein. Lane 5 contains $3 \mu \mathrm{g}$ calf lens fiber EDTA - extractable proteins (EEP). (b), autoradiograph of corresponding electroblot, after incubation with anti-EEP antiserum and ${ }^{125} \mathrm{I}$-labelled protein $A$.

In Fig. 1a the SDS-gel protein patterns of buffer-washed and urea-treated fiber membranes prepared in Tris-CaCl 2 or in Tris-EDTA buffer are shown. Fig. 1b represents the autoradiograph of the corresponding anti-EEP-treated electroblot. The protein patterns are quite similar for buffer-washed membranes isolated in the presence or absence of calcium (cf. lanes 1 and 3 in Fig. 1a). However, the use of calcium-free buffer solutions greatly affects the protein composition of urea-treated membranes. If isolated in the presence of calcium the latter membranes (Fig. 1a, lane 2) mainly consist of a main intrinsic protein (MIP, MW 26000), a 17500 intrinsic protein and a group of EDTA-extractable proteins, called EEP (MW 30000-38000, Fig. 1a, lane 5; van Raaij et al., 1983a). The latter proteins are absent in the cytoplasm and cytoskeleton of lens fiber cells (van Raaij et al., 1983a). The use of a chelator (EDTA) during the wash steps causes the complete removal of EEP from the membranes (Fig. $1 a$ and b, lanes 3 and 4). These results and the results from in vitro reassociation experiments of EEP with EEP-free calf lens fiber membranes indicate that EEP is bound to the membrane exclusively via calcium ions (van den Eijndenvan Raaij et al., 1985a; Van Raaij et al., 1983b). In the in vitro phosphorylation experiments described below both membrane-bound and purified EEP were used to investigate whether these extrinsic membrane proteins are substrates for protein kinase $\mathrm{C}$.

In vitro phosphorylation of lens fiber membrane proteins

The phosphorylation of urea-treated lens fiber membranes with protein kinase C from mouse brain is shown in Fig. 2. Several membrane preparations were incubated with $\left(\gamma^{32}\right.$ P)ATP and the purified protein kinase $C$ in the additional presence of a 

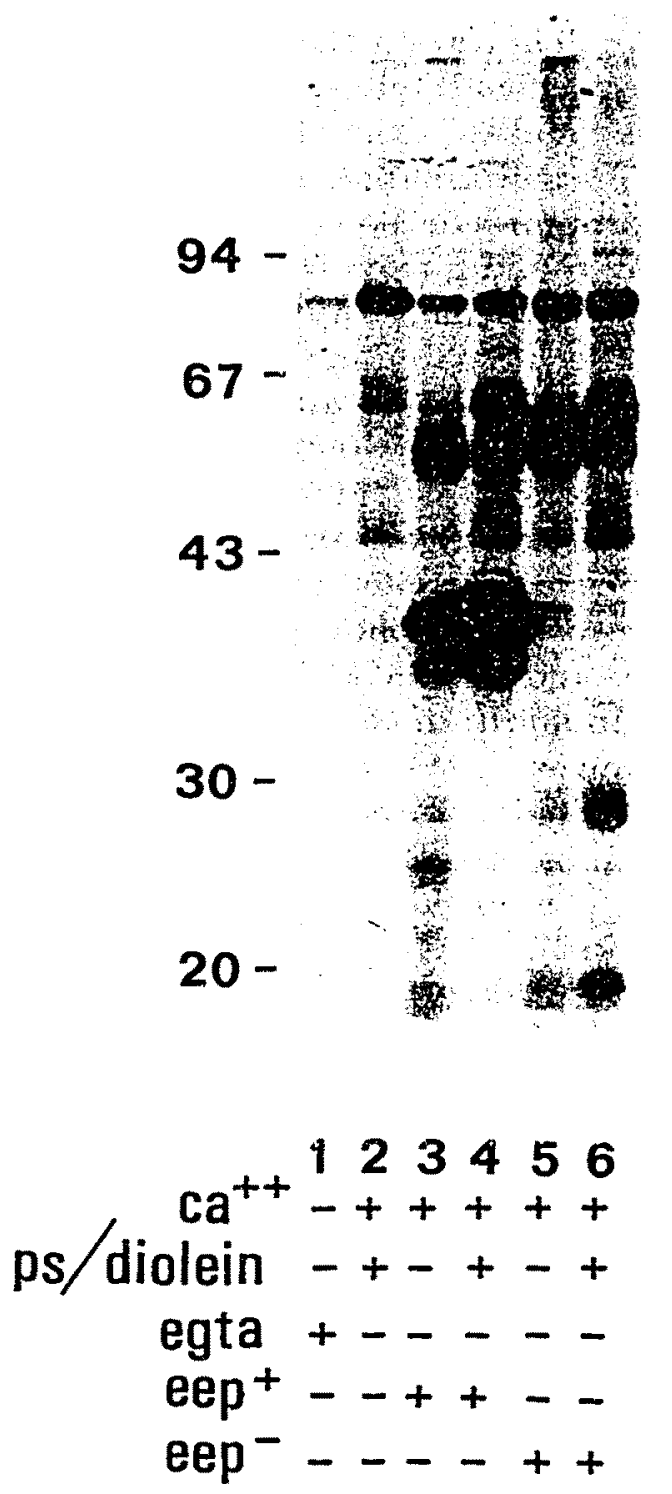

Fia. 2. Autoradiograph of SDS-polyacrylamide gel (10\% gel) containing lens fiber membranes phosphorylated by protein kinase C. Coomassie Blue patterns of the urea-treated membranes containing or lacking EDTA-extractable proteins (EEP) are shown in Fig. 1a, lanes 2 and 4, respectively. The general composition of the incubation mixtures is described in Materials and Methods. Extra additions to the reaction mixture are as indicated. Lanes 1 and 2 contain no lens membranes. In lanes 3 and 4 , EEP-rich urea-treated lens fiber membranes and in lanes 5 and 6 EEP-free membrenes were present during the incubation.

phosphatidylserine (PS)-diolein mixture and (or) calcium. After SDS solubilization the membrane proteins were separated on a $10 \%$ SDS-polyacrylamide gel and analysed by autoradiography. In urea-treated membranes prepared in the presence of calcium, ${ }^{32}$ P label was predominantly associated with EEP provided that calcium was added during the incubation (lanes 3 and 4). The labeled EEP bands directly overlap with the Coomassie Blue-stained EEP bands in this gel (not shown). In the absence of calcium or added protein kinase $C$ no phosphorylation of EEP was observed (not shown). Due to the presence of endogenous phospholipids in the membrane preparations, EEP was phosphorylated with only protein kinase $\mathrm{C}$ and $\mathrm{Ca}^{2+}$ added 
(lane 3). The phosphorylation of EEP in these membranes was further increased by the addition of exogenous PS and diolein during the phosphorylation assay (lane 4). These results indicate that EEP is specifically phosphorylated by protein kinase C in a $\mathrm{Ca}^{2+}$, phospholipid-dependent way and that the fiber membrane preparations used are essentially free of endogenous protein kinase $C$ activity.

Besides EEP, several minor protein components become phosphorylated by protein kinase C. Proteins with MW ranging from 50000-60000 are only observed if membranes are present in the phosphorylation assay (lanes 3-6). As these proteins are still present in urea-treated membranes prepared in the presence of EGTA they might belong to the group of intrinsically located membrane proteins. Considering the results of Lampe et al., (1986) the 50000-60000 MW proteins might represent aggregates of the main intrinsic protein (MW 26000) as well as the 17500 intrinsic protein. The latter proteins are good substrates for protein kinase C (Lampe et al., 1986). Aggregation of these intrinsic proteins which is ane to boiling of the phosphorylated membranes prior to electrophoresis, could also explain the low labeling intensity of the 26000 and $17500 \mathrm{MW}$ protein bands seen on the autoradiogram (Fig. 2, lanes 3-6). In addition to the 50000-60000 proteins a 80000labeled protein band is present. However, this band is also visible after analysis of control reaction mixtures containing only protein kinase $\mathrm{C}$ and no membranes (lane 2). Most probably this 80000 protein band is the result of calcium-and phospholipiddependent autophosphorylation of protein kinase $C$ (lanes 1 and 2 ; Huang, Chan, Singh, Nakabayashi and Huang, 1986).

\section{In vitro phosphorylation of purified EEP}

EEP was eluted from urea-treated lens fiber membranes by means of EDTA. The crude EDTA extract was applied to a Sephadex-G100 gel filtration column resulting in a pure EEP preparation (van Raaij et al., 1983a). On a $10 \%$ SDS-polyacrylamide gel, pure fiber EEP is resolved into eight bands with mrslecular weights of 30000-38000 (Fig. 3a). These proteins bands all represent different monomeric proteins that are biochemically unrelated to any other lens protein (van Raaij et al., 1983a).

In agreement with the results obtained with membrane-bound EEP, pure solubilized EEP is readily phosphorylated by protein kinase $C$ in the simultaneous presence of calcium and a mixture of phosphatidylserine and diolein (Fig. 3b, lane 4). If EEP and (or) calcium are omitted from the incubation mixture no radioactivity can be observed at the position of EEP (lanes 1-3). The absence of contaminating proteins in the EEP preparation provides further evidence that the 80000 protein band represents autophosphorylated protein kinase $\mathrm{C}$.

The extent of ${ }^{32} \mathrm{P}$ label associated with the different EEP protein bands (Fig. $3 \mathrm{~b}$, lane 4) corresponds well with their intensities on a Coomassie-Blue-stained gel (Fig. 3a). The radioactive bands of the EEP pattern consist of the phosphorylated 33000 and 34000 proteins (upper band) and the 30700-31800 proteins (lower band) although discrimination between the individual phosphorylated EEP proteins is difficult on the basis of autoradiography. These results indicate that none of the EEP proteins is preferentially phosphorylated by protein kinase C.

\section{Phosphoaminoacid analysis}

In order to reveal possible differences in phosphorylation patterns of the EEP proteins induced by protein kinase $\mathrm{C}$, phosphoaminoacid determination was carried out on the phosphoproteins. The two major ${ }^{32} \mathrm{P}$-labeled bands of EEP (Fig. 3b, lane 


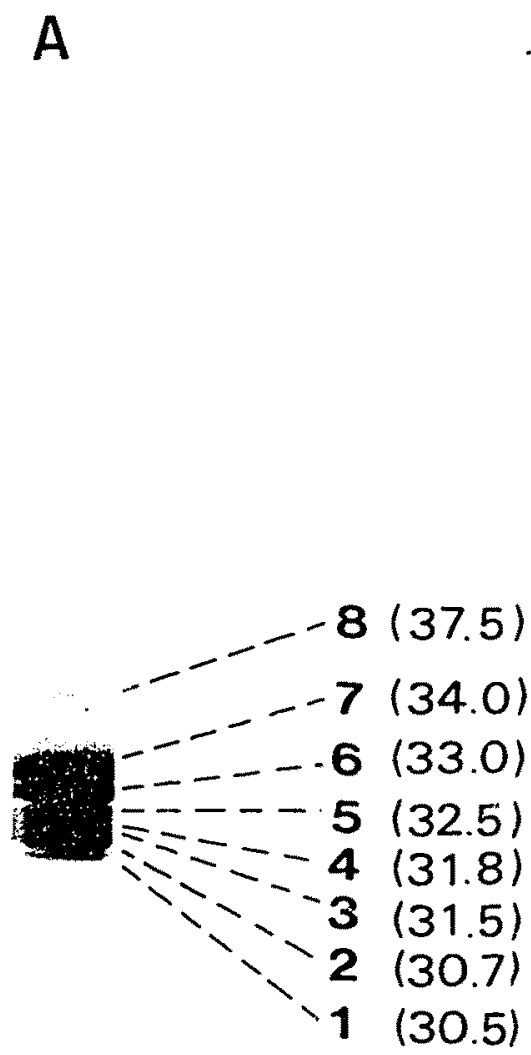

eep
B

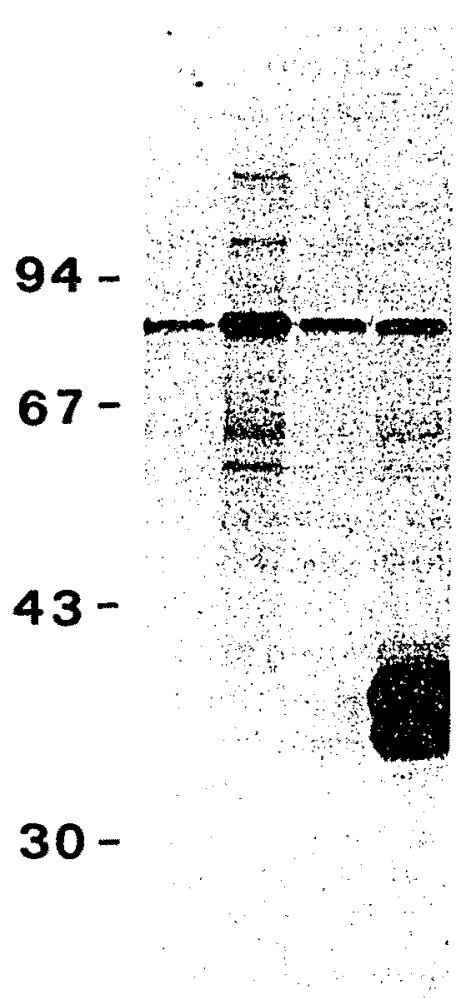

$20-$

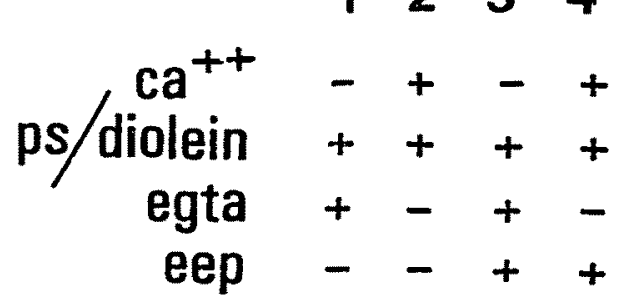

Fig. 3. (a) SDS-gel electrophoresis (10\% gel, $0.75 \mathrm{~mm})$ of purified EDTA-extractable proteins (EEP) $(8 \mu \mathrm{g})$. The apparent molecular weights of the individual bands are shown $\left(\times 10^{-3}\right)$ (mean value of three gels). (b) Autoradiograph of SDS-polyacrylamide gel (10\%) containing purified fiber EEP phosphorylated by protein kinase $C$. The general composition of the reaction mixture is described in Materials and Methods. Extra additions to the reuction mixture are as indicated. EEP was absent (lanes 1 and 2) or present (lanes 3 and 4) during the phosphorylation reaction.

4) were separately cut from the SDS-gel and proteins were eluted from the gel slices prior to acid hydrolysis. Furthermore, the phosphoaminoacid composition of the 80000 protein band was analysed (Fig. $3 \mathrm{~b}$, lanes 2 and 4). The results are shown in Fig. 4. Comparing the label intensities on serine, threonine and tyrosine residues, phosphothreonine appeared to be the only phosphoaminoacid detected for the combined $33000 \mathrm{MW}$ and $34000 \mathrm{MW}$ EEP protein bands (lane 1). On the other hand the label was associated with both phosphothreonine and phosphoserine for the lower radioactive EEP band (lane 2). This difference in phosphoaminoacid patterns was also 


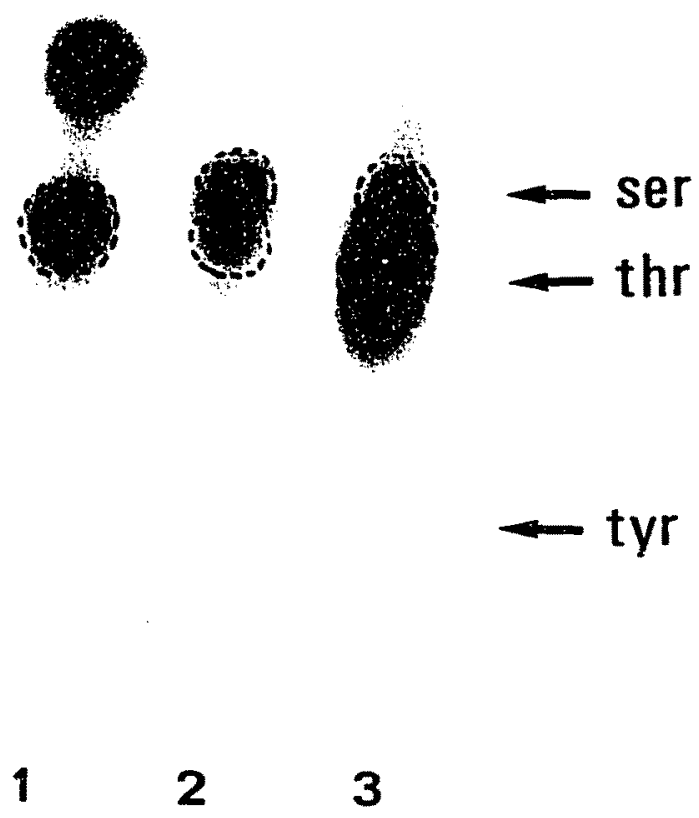

FIG. 4. Phosphoamino-acid analysis of purified EDTA-extractable proteins (EEP) phosphorylated by protein kinase $C$ in vitro. Radioactive bands corresponding to the elution position of the $33000+34000$ MW EEP bands (lane 1), 30700-31800 EEP bands (lane 2) or the 80000 autophosphorylated protein kinase $C$ band (lane 3) were eluted, hydrolysed and analysed as described in Materials and Methods. Labeled phosphoaminoacids were visualized by autoradiography.

observed without dialysis of the proteins after their elution from the gel, indicating that no ${ }^{32} \mathrm{P}$-peptides are lost during the dialysis step. No label was incorporated in tyrosine residues. Protein kinase $\mathrm{C}$ itself is predominantly phosphorylated on threonine residues while during prolonged exposure also a phosphoserine spot is observed. The nature of the spot just above the phosphoserine spot (lanes 1 and 3) is presently unknown. These results are in agreement with the observation that protein substrates for protein kinase $C$ are preferentially phosphorylated on serine and (or) threonine residues (Takai et al., 1982). Furthermore, the difference in phosphoamino-acid patterns of the upper and lower set of EEP protein bands points to a difference in amino-acid sequence between the individual EEP proteins. Such a difference was also shown earlier by peptide mapping of the individual EEP protein bands (van Raaij et al., 1983a).

\section{Discussion}

The results presented in this paper demonstrate that the EDTA-extractable proteins (EEP) from calf lens fiber membranes are phosphorylated in vitro by a calcium- and phospholipid-dependent protein kinase from mouse brain. Recently Lampe et al. (1986) investigated the in vitro phosphorylation of lens membrane proteins by protein kinase $C$ prepared from bovine lens and bovine brain. In contrast with our results no significant phosphorylation could be detected in the 30000-38000 EEP MW range on SDS-polyacrylamide-gel patterns of their phosphorylated membranes. In the study of Lampe et al. (1986), however, EDTA was present in the homogenization buffers during membrane isolation resulting in a EEP-free membrane 
preparation (van den Eijnden-van Raaij et al., 1985a; van Raaij et al., 1983b). Although EDTA was added to ayoid protease activity no significant proteolytic degradation occurs during the preparation of lens membranes even in the presence of calcium (van Raaij et al., 1983b). Thus the use of a chelator only has a negative effect resulting in the removal of a major group of membrane proteins that should not be overlooked in membrane studies.

Analysis of fiber membrane proteins phosphorylated in vivo after incubation of lens tissue with $\left[{ }^{32} \mathrm{P}\right]$ orthophosphate, revealed the presence of label in the 30-38000 MW range which is very probably associated with EEP (Johnson et al., 1986). From this study it is not clear whether the phosphorylation of EEP in vivo, like in vitro, is calcium-and phospholipid-dependent. However, the presence of endogenous protein kinase C activity in the lens (Lampe et al., 1986) and the observation that EEP is a good substrate for this enzyme in vitro (this study) strongly suggest that these extrinsic membrane-bound proteins are phosphorylated in vivo by protein kinase C. As the phosphorylation of EEP in vivo is not significantly enhanced by forskolin or cAMP it is unlikely that a cAMP-dependent protein kinase is also involved in the phosphorylation process (Johnson et al., 1986). Whether still other protein kinase systems are active in the in vivo phosphorylation of EEP needs further investigation.

The function of the EEP proteins and the biological significance of EEP phosphorylation are still unknown. Recently, activation of protein kinase $\mathrm{C}$ and cAMP-dependent protein kinase has been shown to influence the permeability of junctions (Lasater and Dowling, 1985; Piccolino, Gerschenfeld and Neyton, 1984 ; Saez, Spray, Greengard and Bennett, 1985; Gainer and Murray, 1985), structures enabling electrical and metabolic coupling between cells. This result indicates a correlation between protein phosphorylation-dephosphorylation events and the regulation of cell-cell communication via junction structures. As EEP is one of the major protein components of lens fiber membrane fractions enriched in junction-like structures, phosphorylation of these membrane proteins by protein kinase $\mathrm{C}$ in the presence of calcium might be involved in the opening and closing mechanism of lens fiber junctional channels. A similar function has been proposed for MP26 (MIP), another main junctional protein which is also a substrate for protein kinase $C$ (Lampe et al., 1986). Whether phosphorylation of EEP and (or) MP26 (MIP) in vivo indeed has a regulatory role in the functioning of junctions remains to be established.

Within the lens EEP is not only present in the elongated differentiated fiber cells but also in the continuously dividing epithelial cells (Vermorken, Hilderink, Dunia, Benedetti and Bloemendal, 1977). As MP26 (MIP) is absent in the epithelial cell, EEP is the most predominant protein component in the membranes of these cells. Recently EEP was also detected in a number of other non-lenticular cell types, including epithelial and endothelial cells of the cornea and endothelial cells lining blood vessels in a variety of tissues (van den Eijnden-van Raaij, de Leeuw, Winkens, KruisselbrinkBorgonjen and Broekhuyse, 1985b). Some of these cell types have been reported to respond to specific growth and (or) differentiation factors by rapidly increasing theii cell number or by aquiring the morphology of a differentiated cell, respectively. For instance FGF-like growth factors stimulate the growth of lens epithelial cells (Schreiber et al., 1985a; Courty et al., 1985) and of endothelial cells, (Gospodarowicz, Massaglia, Cheng, Lui and Bohlen, 1985; Schreiber et al., 1985b) while lentropin induces differentiation of lens epithelial cells (Beebe et al., 1980).

In a recent paper Tsuda, Kaibuchi, Kawahara, Fukuzaki and Takai (1985) have shown that FGF rapidly induces diacylglycerol formation, protein kinase $\mathrm{C}$ activation 
and $\mathrm{Ca}^{2+}$ mobilization in quiescent Swiss 3T3 cells. They suggested that diacylglycerol and $\mathrm{Ca}^{2+}$ serve as second messengers in the mitogenic action of this growth factor. In this regard it is possible that protein kinase $\mathrm{C}$ is activated by FGF-like growth factors and (or) other growth factors in lens epithelial cells and the other cell types described above. Considering the resuits presented in this paper protein kinase $C$ activation might in turn result in the phosphorylation of EEP. However, further bionhemical investigations are necessary to reveal the possible involvement of EEP in the cascade of signals that finally cause cell growth or differentiation.

\section{ACKNOWLEDGMENT}

The authors wish to thank Dr R. M. Broekhuyse and Mr A. L. M. de Leeuw, Department of Ophthalmology, University of Nijmegen, for the generous supply of membranes and EEP from calf lens fiber cells.

\section{REFERENCES}

Barritault, D., Arruti, C. and Courtois, Y. (1981). Is there a ubiquitous growth factor in the eye? Differentiation 18, 29-42.

Beebe, D. C., Feagans, D. E. and Jebens, H. A. (1980). Lentropin : a factor in vitreous humor which promotes lens fiber celi differentiation. Proc Nal. Acad. Sci. U.S.A. 77, 490-3.

Berridge, M. J., Heslop, J. P., Irvine, R. F. and Brown, K. D. (1984). Inositol triphosphate formation and calcium mobilization in Swiss $3 \mathrm{~T} 3$ cells in response to platelet-derived growth factor. Biochem. J. 222, 195-201.

Bloemendal, H. (1981). The lens proteins. In Molecular and Cellular Biology of the Eye Lens. (Ed. Bloemendal, H.) Pp. 1-48. John Wiley and Sons: New York.

Bloemendal, H. (1982). Lens proteins. CRC Crit. Rev. in Biochem. 12, 1-38.

Bradford. M. M. (1976). A rapid and sensitive method for the quantitation of microgram quantities of protein utilizing the principle of protein-dye binding. Anal. Biochem. 72, 248-54.

Broekhuyse, R. M. (1981). Biochemistry of membranes. In Mechanisms of Cataract Formation in the Human Lens. (Ed. Duncan, G.) Pp. 151-91. Academic Press: London.

Courty, J., Loret, C., Moenner, M., Chevallier, B., Lagente, O., Courtois, Y. and Barritault, D. (1985). Bovine retina contains three growth factor activities with different affinity for heparin: eye-derived growth factor I, II and III. Biochimie 67, 265-9.

Van den Eijnden-van Raaij, A. J. M., de Leeuw, A. L. M. and Broekhuyse, R. M. (1985a). In vitro reassociation of EDTA-extractable proteins with calf lens fiber membranes. $E x p$. Eye Res. 40, 477-87.

Van den Eijnden-van Raaij, A. J. M., de Leeuw, A. L. M., Winkens, H. J., KruisselbrinkBorgonjen, J.F.J. and Broekhuyse, R.M. (1985b). Biochemical and histochemical characteristics of proteins homologous to calf lens membrane proteins with high calcium-binding capacity. Exp. Cell Res. 159, 519-30.

Gainer, H. and Murray, A. (1985). Diacylglycerol inhibits gap junctional communication in cultured epidermal cells : evidence for a role of protein kinase C. Biochem. Biophys. Res. Commun. 126, 1109-13.

Gospodarowicz, D., Massoglia, S., Cheng, J., Lui, G. M. and Bohlen, P. (1985). Isolation of pituitary fibroblast growth factor by fast protein liquid chromatography (FPLC): partial chemical and biological characterization. J. Cell. Physiol. 122, 323-32.

Habenicht, A. J. R., Glomset, J. A., King, W. C, Nist, C., Mitchell, C. D. and Ross, R. (1981). Early changes in phosphatidylinositol and arachidonic acid metabolism in quiescent Swiss 3T3 cells stimulated to divide by platelet-derived growth factor. J. Biol. Chem. 256, $12329-35$.

Harding, J. J. and Dilley, K. J. (1976). Structural proteins in the mammalian lens : a review with emphasis on changes in development, aging and cataract. Exp. Eye Res. 22, $1-73$.

Huang, K. P., Chan, K. F. J., Singh, T. J., Nakabayashi, H. and Huang, F. L. (1986). 
Autophosphorylation of rat brain $\mathrm{Ca}^{2+}$-activated and phospholipid-dependent protein kinase. J. Biol. Chem. 261, 12134-40.

Inoue, M., Kishimoto, A., Takai, Y. and Nishizuka, Y. (1977). Studies on a cyclic nucleotideindependent protein kinase and its proenzyme in mammalian tissues. J. Biol. Chem. 252, $7610-6$.

Johnson, K. R., Lampe, P. D., Chung Hur, K., Louis, C. F. and Johnson, R. G. (1986). A lens intercellular junction protein, MP26, is a phosphoprotein. J. Cell Biol. 102, 1334-43.

Lampe, P. D., Bazzi, M. D., Nelsestuen, G. L. and Johnson, R. G. (1986). Phospinorylation of lens intrinsic membrane proteins by protein kinase C. Eur. J. Biochem. 156, 351-7.

Laemmli, U.K. (1970). Cleavage of structural proteins during the assembly of the head of bacteriophage T4. Nature (London) 227, 680-5.

Lasater, E. M. and Dowling, J. E. (1985). Dopamine decreases conductance of the electrical junctions between cultured retinal horizontal cells. Proc. Nat. Acad. Sci. U.S.A. 82, 3025-9.

Lees, M. B. and Paxman, S. (1972). Modification of the Lowry procedure for the analysis of proteolipid protein. Anal. Biochem. 72, 248-54.

Moenner, M., Chevallier, J., Badet, J. and Barritault, D. (1986). Evidence and characterization of the receptor to eye-derived growth factor $I$, the retinal form of fibroblast growth factor, on bovine epithelial lens cells. Proc. Nat. Acad. Sci. U.S.A. 83, 5024-8.

Nishizuka, Y. (1984a). The role of protein kinase $C$ in cell surface signal transduction and tumour production. Nature (London) 308, 693-8.

Nishizuka, Y. (1984b). Turnover of inositol phospholipids and signal transduction. Science $225,1365-70$.

Piccolino, M., Gerschenfeld, H. M. and Neyton, J. (1984). Decrease of gap junction permeability induced by dopamine and cyclic-AMP in horizontal cells of turtle retina. J. Neurosci. 4, 2477-88.

Van Raaij, A. J. M., de Leeuw, A. L. M. and Broekhuyse, R. M. (1983a). Charge and molecular weight heterogeneity of EDTA-extractable proteins from calf lens fiber membranes. Exp. Eye Res. 36, 719-29.

Van Raaij, A. J. M., de Leeuw, A. L. M. and Broekhuyse, R. M. (1983b). Calcium-dependent binding of EDTA-extractable proteins to calf lens fiber membrane structures. Biochim. Biophys. Acta 736, 67-72.

Van Raaij, A. J. M., de Leeuw, A. L. M., Janssen, A. P. M. and Broekhuyse, R. M. (1983c). Immunological relationship between the EDTA-extractable proteins from calf lens fiber membranes. Exp. Eye Res. 37, 183-90.

Saez, J. C., Spray, D. C., Hertzberg, E. L., Nairn, A. C., Greengard, P. and Bennett, M. V. L. (1985). Modulation of gap junctional conductance in hepatocytes by cAMP: is protein phosphorylation involved ? J. Cell Biol. 101, 178a.

Schreiber, A. B., Kenney, J., Kowalski, W. J., Friesel, R., Mehlman, T. and Maciag, T. $(1985 \mathrm{~b})$. Interaction of endothelial cell growth factor with heparin : characterization by receptor and antibody recognition. Proc. Nat. Acad. Sci. U.S.A. 82, 6138-42.

Schreiber, A. B., Kenney, J., Kowalsky, W. J., Thomas, K. A., Gimenez-Gallego, G., RiosCandelore, M., DiSalvo, J., Barritault, D., Courty, J., Courtois, Y., Moenner, M., Burgess, W. M., Mehlman, T., Friesel, T., Johnson, W. and Maciag, T. (1985a). A unique family of endothelial cell polypeptide mitogens : the antigenic and receptor cross-reactivity of bovine endothelial cell growth factor, brain-derived acidic fibroblast growth factor, and eye-derived growth factor-II. $J$. Cell Biol. 101, 1623-6.

Snoek, G. T., Rosenberg, I., de Laat, S. W. and Gitler, C. (1986). The interaction of protein kinase $C$ and other specific cytoplasmic proteins with phospholipid bilayers. Biochim. Biophys. Acta 860, 336-44.

Takai, Y., Kishimoto, A. and Nishizuka, Y. (1982). Calcium and phospholipid turnover as transmembrane signaling for protein phosphorylation. In Calcium and Cell Function. (Ed. Cheung, W. J.) Pp. 386-413. Academic Press: New York, London.

Tsuda, T., Kaibuchi, K., Kawahara, Y., Fukuzaki, H. and Taka, Y. (1985). Induction of protein kinase $\mathrm{C}$ activation and $\mathrm{Ca}^{2+}$ mobilization by fibroblast growth factor in Swiss 3 T3 cells. FEBS Lett. 191, 205-10.

Vermorken, A. J. M., Hilderink, J. M. H. C., Dunia, I., Benedetti, E. L. and Bloemendal, H. (1977). Changes in membrane pattern in relation to lens cell differentiation. FEBS Letts. 301-6. 